\title{
Erratum Arq Bras Oftalmol. 2011;74(4):306-10
}

Errata Arq Bras Oftalmol. 2011;74(4):306-10

Yara Dadalti Fragoso 1

Editor in Chief

Arquivos Brasileiros de Oftalmologia

Dear Prof Wallace

I write to you in regard to our publication "Literature systematic review on the ophthalmological side effects of interferons" (Arq Bras Oftalmol. 2011;74(4):306-10).

It came to my attention, due to an e-mail sent to me by Dr. ShihChen Chang, that the cited reference number 84 in the text should be addressed to reference 85 . The text statement is correct, but we would like to make an erratum, stating that reference 85 (Narkewicz $M R$, et al.) should replace reference 84 (Kabbaj $N$, et al.) in the paragraph that mentions side effects of interferons in children.

Thank you for the opportunity to correct our mistake.

Yours sincerely

Yara Dadalti Fragoso

Submitted for publication: May 15, 2012

Accepted for publication: May 15,2012

Correspondence address: Yara Dadalti Fragoso. Faculdade de Medicina UNIMES - Rua da Cons-

Professor, Setor de Neurologia, Universidade Metropolitana de Santos - UNIMES - Santos (SP), Brazil;

\section{Conselho Brasileiro de Oftalmologia}

